\title{
Grain Yield Performance of Biofortified Climbing Common Bean Genotypes (Phaseolus Vulgaris L.) Evaluated Across Different Agro-ecologies in Tanzania
}

\author{
Shida Nestory ${ }^{1} \quad$ Mary Mdachi $^{1} \quad$ Magdalena William $^{2} \quad$ Edith Kadege $^{1} \quad$ Godfrey Kessy ${ }^{1}$ \\ Demetria Mugunda $^{1} \quad$ John Msaky $^{1} \quad$ Jean Claude Rubyogo $^{3}$ \\ 1.Ministry of Agriculture, Selian Agricultural Research Institute, Arusha Tanzania \\ 2.Ministry of Agriculture, Maruku Agricultural Research Institute, Bukoba Tanzania \\ 3.International Centre for Tropical Agriculture, Arusha Tanzania
}

\begin{abstract}
Assessment study on yield performance and consumer preferences characteristics of iron and zinc fortified bean genotypes was conducted between 2014/15 and 2015/16 seasons at different agro-ecologies of Tanzania. The objective of the study was to improve nutrition and income of smallholder farmers through growing and selling of high yielding and iron bean genotypes. The experiments consisted of five high iron enhanced climbing common bean genotypes namely: MAC 44 (80.3 mg/kg), RWV (78 mg/kg), MAC9 (64 mg/kg), MAC49 (66.6 mg/kg) and Selian $(35.2 \mathrm{mg} / \mathrm{kg})$. These planting materials were planted in Randomized Complete Block Design (RCBD) with three replications in Arusha at ARI-Selian farm, Lambo in Kilimanjaro, ARI-Uyole in Mbeya and in Kagera at ARI-Maruku. The sites ARI-Selian and Maruku represented mid altitude agro-ecologies, ARI Uyole (high altitude) and Lambo site is low agro-ecology. Grain yield and disease reaction scores data was collected and analysed using GenStat $15^{\text {th }}$ edition software. Results showed significance difference $(\mathrm{P} \leq 0.05)$ for grain yield and diseases. Grain yield ranged from $1538 \mathrm{~kg} / \mathrm{ha}$ to $4314 \mathrm{~kg} / \mathrm{ha}$. Genotype RWV1129 produced $3091 \mathrm{~kg} / \mathrm{ha}$ in 2014/2015 where as MACC44 yielded relatively higher (3530kg/ha than RWV1129 at Selian site in 2015/2016 season. The farmers' participatory variety selection approach used in selecting of new improved bean genotypes depicted high yield, high market demanded, and resistant to diseases as the key important criteria. Genotypes MACC44 and RWV 1129 were the best genotypes accepted by farmers due to their high yield, and high market value. Therefore, the study recommended them to be registered and released as nutritionally improved varieties for farmers' cultivation and consumption thereby to relief the iron deficient vulnerable groups in Tanzania.
\end{abstract}

Keywords: Climbing bean, Biofortification, Performance, Iron and Zinc

DOI: $10.7176 / \mathrm{JBAH} / 9-4-06$

\section{Introduction}

Common bean is the $3^{\text {rd }}$ important world grain legume after soybean (Glycine max) and peanut (Arachis hypogeal L.) (Lin et al., 2008). It is an important key source and supplier of protein, dietary fiber, minerals and vitamins to the feeding population in the world, particularly Latin America and Eastern Africa (Petry et., 2015). Morphologically, common bean is characterized by two types of growth namely climbing and bush growth types (Checa et al, 2006). Climbing bean has higher yield (4-5 t/ha) than bush types (1 to $2 \mathrm{t} / \mathrm{ha}$ ) (Kaizzi et al., 2012). Major common bean producers in Africa include Tanzania, Uganda, Kenya, Ethiopia and Rwanda which produce more than 3 million tons of bean per year (FAOSTAT, 2012). Tanzania earns more than 145,906,000 US dollar per annum from export of different common bean varieties produced in the country (FAOSTAT, 2012). The major growing regions in Tanzania include Arusha, Kilimanjaro, Manyara and Tanga in the Northern zone; Kagera and Geita in the Lake zone; Kigoma in the Western zone; and Mbeya, Songwe, Iringa, Sumbawanga and Njombe in the Southern Highlands zone (FAOSTAT, 2012). Though common bean is grown widely in Tanzania and considered to be rich in terms of iron and protein yet about $44 \%$ of children under 5 years in this country are showing iron-deficiency symptoms while $72 \%$ of them are purely anemic. Over $50 \%$ of woman and preschool children in developing countries have iron-deficiency anaemia which causes death and impair physical and mental development (Blair, 2013). This problem is accelerated by feeding from poor or low nutritional foodstuffs (Muhimbula and Zacharia, 2010). Development and introduction of bean genotypes with improved yield potential, enriched in micronutrients combined with agronomic traits of preference to farmers would bring sustainable solution to current problem of iron deficiency in the country. Common bean germplasm with improved nutrition status through fortification approaches are available at International Centers for Tropical Agriculture (CIAT) in Uganda and Rwanda. These germplasms can be sourced out and tested across different farmers' growing conditions in Tanzania. Therefore, the main objective of this study was to improve income and nutrition status of smallholder farmers through growing of high yielding, iron and zinc fortified beans genotypes in Tanzania. The specific objectives were to introduce and assess the grain yield performance and consumer characteristics of iron and zinc fortified bean genotypes. 


\section{Materials and Methods}

Plant material and study area

Five fortified high iron and zinc climbing bean genotypes were collected from International Center for Tropical Agriculture-Uganda, and Rwanda by SARI. The bean genotypes collected were tested under rain fed conditions in different sites, agro ecologies and seasons (Table 1).

Table 1: Study sites

\begin{tabular}{|l|l|l|l|l|l|}
\hline Site & Region & $\begin{array}{l}\text { Elevation }(\mathrm{m}) \\
\text { above sea level }\end{array}$ & Agro-ecological level & \multicolumn{2}{|c|}{ Planting season } \\
\cline { 5 - 6 } & & & & $2014 / 15$ & $2015 / 16$ \\
\hline ARI-Selian & Arusha & 1380 & Mid altitude & $2014 / 15$ & $2015 / 16$ \\
\hline ARI-Uyole & Mbeya & 1850 & High altitude & $2014 / 15$ & $2015 / 16$ \\
\hline ARI- Maruku & Kagera & 1300 & Mid-altitude & $2014 / 15$ & $2015 / 16$ \\
\hline Lambo & Kilimanjaro & 985 & Low altitude & $2014 / 15$ & $2015 / 16$ \\
\hline
\end{tabular}

Experiment was laid out in Randomized Complete Block Design (RCBD) with 3 replications. The plot size was 4 rows each with 5 meters long, spaced $50 \mathrm{~cm}$ between rows and $25 \mathrm{~cm}$ within a row, two seeds per hill were sowed Basal fertilizer Diammonium phosphate (DAP) was applied at planting at the rate of $130 \mathrm{~kg}$ per hectare. The net plot size was $4.25 \mathrm{~m}^{2}$ across the testing sites. Two weeding were done after planting using hand hoe. Disease scores were collected by observing the lesion of the disease and rate through scale of 1-9 CIAT protocol, 1 being non-pathogenic and 9 being highly pathogenic. The, diseases observed in this study included angular leaf spot, anthracnose, and common bacterial blight. Diseases and yield data were collected from the two centre rows from each plot. Grain yield was calculated from the field weight of each plot harvested by using the formula proposed by CIAT protocol. Data were analyzed using GenStat Release 15 (PC/Windows 8) Copyright 2013, VSN International Ltd means separation done using Duncan test at 5\% and linear model used.

\section{Farmer's participatory variety selection}

About 13 farmers ( 6 female and 7 men) participated in selection of the best bean candidates, which suits for their growing environments and having other preference consumption traits. Farmers walked through and observe each plot of the five climbing bean genotypes; and describe each genotype based on their views, Farmers described each genotype based on the seed color, number of seed in a pod, number of pods per plant/plot, drought tolerant, seed shape, maturity duration, reaction to diseases, and market of the grain through passing within and between genotypes plots. Also, farmers asked to mention and rank five criteria for adopting a new bean variety to grow in their area, which will be used on the pairwise and matrix ranking approach. Through matrix ranking approach, farmers were given opportunity to rank the genotypes in which position they should take or be by mentioning the scale number corresponding to the criteria being established. The score scale used is 1-5, as 1 indicating poor, 2satisfactory, 3-average, 4-good and 5- excellent. Participants were allowed to make comparison between the candidate bean genotypes planted in the experiment. This work was done by comparing 2 genotypes at a time. The candidate genotype with highest scores against others on the table was considered as the best for selection.

\subsection{Results}

3.1 Grain yield and agronomic performance of climbing bean genotypes evaluated in 2014/2015 season Analysis of variance (ANOVA) showed significance difference at $(\mathrm{P} \leq 0.05)$ for grain yield. Mean grain yield in 2014/2015 season ranged from $1538 \mathrm{~kg} / \mathrm{ha}$ recorded by Maruku site to $4314 \mathrm{~kg} / \mathrm{ha}$ recorded by Lambo site (Table 2). GenotypeWRV1129 had highest grain yield at Selian and Uyole sites while MAC44 outperformed the local check (selian06) in Maruku and Lambo. Infestation with angular leaf spot showed significance difference $(\mathrm{P} \leq 0.05)$ with the highest score of 3 recorded at Selian location only (Table 2).

\subsection{Grain yield and agronomic performance of climbing bean genotypes evaluated in 2015/2016 season}

In the season 2015/2016 grain yield of RWV1129 was generally high across locations with highest yield of $3091 \mathrm{~kg} / \mathrm{ha}$ being recorded at Selian site. The lowest grain yield of $1965 \mathrm{~kg} / \mathrm{ha}$ was recorded at Lambo in the northern zone. MAC44 performed relatively high in Maruku site when compared with RWV1129. Angular leaf spot was significant difference $(\mathrm{P} \leq 0.05)$ at ARI-Selian, ARI-Uyole and ARI-Maruku locations with the highest score of 4.0 at Maruku location for Local check (Selian06). Common bacterial bright recorded to be significance $(\mathrm{P} \leq 0.05)$ at ARI-Uyole and ARI-Maruku locations with score range from 1.0 to 3.7 for local check (Selian06).

\subsection{Farmer's participatory variety selection}

From both two approaches of conducting farmers' assessment study, the two climbing bean genotypes namely RWV1129 and MAC 44 were preferred at their local areas. In Bukoba farmers chosen RWV 1129 followed with MAC 44 on pairwise ranking and matrix approach while stating clearly that drought tolerance and high yield were respectively first and second criteria for selecting best new bean genotypes to grow followed by diseases and pest resistance as a third criterion. Farmers in Arusha also selected MAC 44 as first best new climbing bean to grow. 
(Table 4, Table 5, Table 6 and Table 7).

Table 2: Grain yield performance and disease score of climbing bean genotypes at Uyole, Maruku, Lambo and Selian sites 2014/2015 season

\begin{tabular}{|c|c|c|c|c|c|c|c|c|c|c|c|c|c|c|c|c|}
\hline \multicolumn{5}{|c|}{ Uyole } & \multicolumn{4}{|c|}{ Maruku } & \multicolumn{3}{|c|}{ Lambo } & \multirow[b]{2}{*}{$\begin{array}{l}\text { Yield } \\
\mathrm{Kg} / \mathrm{ha}\end{array}$} & \multicolumn{4}{|c|}{ Selian } \\
\hline $\begin{array}{l}\text { Genotype } \\
\text { variables }\end{array}$ & ALS & ANTH & CBB & $\begin{array}{l}\text { Yield } \\
\mathrm{Kg} / \mathrm{ha}\end{array}$ & ALS & ANTH & $\mathrm{CBB}$ & $\begin{array}{l}\text { Yield } \\
\mathrm{Kg} / \mathrm{ha}\end{array}$ & ALS & ANTH & CBB & & ALS & ANTH & CBB & $\begin{array}{l}\text { Yield } \\
\mathrm{Kg} / \mathrm{hg}\end{array}$ \\
\hline MAC44 & 1.0 & 1.0 & 1.0 & 2841 & 1.0 & 1.0 & 1.0 & 2027 & 1.3 & 1.0 & 1.0 & 3530 & 1.0 & 1.0 & 2.0 & 2086 \\
\hline MAC49 & 1.0 & 1.0 & 1.0 & 2839 & 1.0 & 1.0 & 2.0 & 1606 & 1.3 & 1.0 & 1.0 & 4314 & 1.0 & 1.0 & 2.0 & 2143 \\
\hline MAC9 & 2.0 & 1.0 & 2.0 & 2400 & 2.0 & 1.0 & 1.0 & 1538 & 2.0 & 1.0 & 2.0 & 2863 & 1.0 & 1.0 & 2.0 & 1933 \\
\hline RWV1129 & 3.0 & 1.0 & 1.0 & 3398 & 1.3 & 1.0 & 1.0 & 1892 & 2.3 & 1.0 & 1.0 & 3169 & 1.0 & 1.0 & 2.0 & 2452 \\
\hline Selian 06 & 2.0 & 1.0 & 1.0 & 2792 & 2.0 & 1.0 & 2.0 & 1980 & 3.3 & 1.0 & 1.0 & 3240 & 1.0 & 1.0 & 1.0 & 2192 \\
\hline Mean & 2.0 & 1.0 & 1.0 & 2854 & 1.5 & 1.0 & 1.0 & 1809 & 2.1 & 1.0 & 1.0 & 3423 & 1.0 & 1.0 & 2.0 & 2161 \\
\hline $\mathrm{Cv} \%$ & 68 & & 57 & 27.7 & 35 & 34 & 50 & 11.6 & 61 & 1.0 & - & 31.7 & - & - & 34 & 10.6 \\
\hline Lsd & 2.0 & & 1.0 & 1616 & 1.0 & 1.0 & 1.0 & 394 & 2.4 & 2.0 & - & 2044 & - & - & 1 & 432 \\
\hline$P \leq 0.05$ & $*$ & ns & $\mathrm{ns}$ & $*$ & ns & ns & $\mathrm{ns}$ & $*$ & ns & $\mathrm{ns}$ & ns & $*$ & ns & ns & $\mathrm{ns}$ & $*$ \\
\hline
\end{tabular}

Key: ALS-Angular leaf spot, ANTH-Anthracnose, CBB-Common bacterial bright, kg/ha-Kilogram per hectare, Lsd-Least significant different, ns- not significant, *- Significant.

Table 3: Grain yield performance and disease score of climbing bean genotypes at Uyole, Maruku, Lambo and Selian sites 2015/2016 season

\begin{tabular}{|c|c|c|c|c|c|c|c|c|c|c|c|c|c|c|c|c|}
\hline \multicolumn{5}{|c|}{ Uyole } & \multicolumn{4}{|c|}{ Maruku } & \multicolumn{3}{|c|}{ Lambo } & \multirow[b]{2}{*}{$\begin{array}{l}\text { Yield } \\
\mathrm{Kg} / \mathrm{ha}\end{array}$} & \multicolumn{4}{|c|}{ Selian } \\
\hline $\begin{array}{l}\text { Genotype } \\
\text { variables }\end{array}$ & ALS & ANTH & CBB & $\begin{array}{l}\text { Yield } \\
\mathrm{Kg} / \mathrm{ha}\end{array}$ & ALS & ANTH & CBB & $\begin{array}{l}\text { Yield } \\
\mathrm{Kg} / \mathrm{ha}\end{array}$ & ALS & ANTH & $\mathrm{CBB}$ & & ALS & ANTH & CBB & $\begin{array}{l}\text { Yield } \\
\mathrm{Kg} / \mathrm{ha}\end{array}$ \\
\hline MAC44 & 2.0 & 1.0 & 2.3 & 2582 & 2.33 & 1.0 & 2.0 & 2787 & 1.3 & 1.0 & 2.0 & 2353 & 1.3 & 1.0 & 1.0 & 2910 \\
\hline MAC49 & 2.0 & 1.0 & 2.3 & 2455 & 2.33 & 1.0 & 1.7 & 2552 & 2.3 & 1.0 & 2.0 & 2143 & 2.3 & 1.0 & 1.0 & 3059 \\
\hline MAC9 & 1.0 & 1.0 & 1.7 & 2473 & 2.0 & 1.0 & 10 & 2549 & 2.0 & 1.0 & 2.0 & 1965 & 3.3 & 1.0 & 2.0 & 2628 \\
\hline RWV1129 & 3.0 & 1.0 & 2.0 & 2847 & 2.0 & 1.0 & 10 & 2760 & 1.3 & 1.0 & 2.0 & 2539 & 2.3 & 1.0 & 2.0 & 3091 \\
\hline Selian06 & 1.0 & 1.0 & 3.7 & 2712 & 4.0 & 1.0 & 2.7 & 2458 & 3.3 & 1.0 & 2.0 & 2184 & 3.7 & 1.0 & 2.0 & 2675 \\
\hline Mean & 2.0 & 1.0 & 2.4 & 2614 & 2.5 & 1.0 & 1.9 & 2621 & 2.1 & 1.0 & 2.0 & 2236 & 2.6 & 1.0 & 2.0 & 2873 \\
\hline $\mathrm{Cv} \%$ & 47 & 24 & 27 & 9.9 & 31.8 & 17 & 31 & 11.1 & 61 & 9.0 & 16 & 8.3 & 18 & 23 & 39 & 17.4 \\
\hline Lsd & 1.0 & 0.5 & 1.2 & 486 & 1.5 & 0.5 & 1.1 & 550 & 2.4 & 0.2 & 1.0 & 350 & 0.9 & 0.2 & 1.0 & 941 \\
\hline $\mathrm{P}=0.05$ & $*$ & ns & $*$ & $*$ & $*$ & $\mathrm{~ns}$ & $*$ & $*$ & ns & $\mathrm{ns}$ & ns & $*$ & $*$ & ns & ns & $*$ \\
\hline
\end{tabular}

Key: ALS-Angular leaf spot, ANTH-Anthracnose, CBB-Common bacterial bright, kg/ha-Kilogram per hectare, Lsd-Least significant different, ns-not significant, *- Significant.

Table 4: Matrix ranking approach results in Dareda -Arusha for climbing bean genotypes selection assessment.

\begin{tabular}{lccccccc}
\hline \multirow{2}{*}{ Criteria } & \multicolumn{4}{c}{ Bean genotypes scored } & \multicolumn{2}{c}{ Total } & Rank \\
\cline { 2 - 9 } & MAC49 & Selian 06 & MAC44 & MAC9 & RWV1129 & & $\mathbf{2}$ \\
\hline High yield & 2 & 4 & 4 & 3 & 5 & $\mathbf{1 8}$ & $\mathbf{4}$ \\
\hline Drought tolerance & 2 & 3 & 4 & 2 & 5 & $\mathbf{1 6}$ & $\mathbf{1}$ \\
\hline Good market & 2 & 4 & 4 & 4 & 5 & $\mathbf{1 9}$ & $\mathbf{1}$ \\
\hline Disease \& pest tolerance & 3 & 3 & 4 & 3 & 4 & $\mathbf{1 7}$ & $\mathbf{3}$ \\
\hline Early maturity & 2 & 4 & 4 & 3 & 5 & $\mathbf{1 8}$ & $\mathbf{2}$ \\
\hline Total & $\mathbf{1 1}$ & $\mathbf{1 8}$ & $\mathbf{2 0}$ & $\mathbf{1 5}$ & $\mathbf{2 4}$ & & $\mathbf{1}$ \\
Rank & $\mathbf{5}$ & $\mathbf{3}$ & $\mathbf{2}$ & $\mathbf{4}$ & $\mathbf{1}$
\end{tabular}

Key: 1-poor, 2-Satisfactory, 3-Average, 4-Good, 5-Excellent

Table 5: Pair wise ranking approach results in Dareda -Arusha for climbing bean genotypes selection assessment.

\begin{tabular}{llllllll}
\hline & RWV1129 & MAC9 & MAC44 & Selian 06 & MAC49 & Total & Rank \\
\hline RWV1129 & & RVW1129 & MAC44 & RWV1129 & RWV129 & 3 & 2 \\
MAC9 & & MAC44 & Selian 06 & MAC9 & 1 & 4 \\
MAC44 & & & & MAC44 & MAC44 & 4 & 1 \\
Selian 06 & & & & Selian 06 & 2 & 3 \\
MAC49 & & & & & 0 & 5 \\
\hline
\end{tabular}


Table 6: Matrix ranking approach results in Kitengule-Bukoba for climbing bean genotypes selection assessment

\begin{tabular}{lccccccc}
\hline Criteria & \multicolumn{2}{c}{ Bean genotypes scored } & & & & Total & Rank \\
& MAC49 & Selian06 & MAC44 & MAC9 & RWV1129 & & \\
\hline High yield & 3 & 4 & 4 & 2 & 5 & $\mathbf{1 8}$ & $\mathbf{2}$ \\
\hline Drought tolerance & 2 & 4 & 4 & 4 & 5 & $\mathbf{1 9}$ & $\mathbf{1}$ \\
\hline Good market & 2 & 3 & 4 & 2 & 5 & $\mathbf{1 6}$ & $\mathbf{4}$ \\
\hline Disease \& pest tolerance & 3 & 3 & 4 & 3 & 4 & $\mathbf{1 7}$ & $\mathbf{3}$ \\
\hline Early maturity & 2 & 4 & 4 & 3 & 5 & $\mathbf{1 8}$ & $\mathbf{2}$ \\
\hline Total & $\mathbf{1 1}$ & $\mathbf{1 8}$ & $\mathbf{2 0}$ & $\mathbf{1 5}$ & $\mathbf{2 4}$ & & \\
Rank & $\mathbf{5}$ & $\mathbf{3}$ & $\mathbf{2}$ & $\mathbf{4}$ & $\mathbf{1}$ & & \\
\hline
\end{tabular}

Key: 1-Poor, 2-Satisfactory,3-Average,4-Good, 5-Excellent

Table 7: Pair wise ranking approach results in Kitengule-Bukoba for climbing bean genotypes selection assessment

\begin{tabular}{llllllll}
\hline & RWV1129 & MAC9 & MAC44 & Selian 06 & MAC49 & Total & Rank \\
\hline RWV1129 & & RVW1129 & RWV1129 & RWV1129 & RWV129 & 4 & 1 \\
MAC9 & & MAC44 & Selian 06 & MAC9 & 1 & 4 \\
MAC44 & & & MAC44 & MAC44 & 3 & 2 \\
Selian 06 & & & & Selian 06 & 2 & 3 \\
MAC49 & & & & & 0 & 5 \\
\hline
\end{tabular}

\subsection{DISCUSSION}

High grain yield $4314 \mathrm{~kg} /$ ha obtained from the results of evaluating high iron fortified climbing bean implies that introduced high iron fortified bean genotypes could be grown successfully by farmers in Tanzania to improve their healthy and income. Variation in grain yield, drought tolerance potential as well as in disease infection reported in this study provide opportunities for breeders to select the superior genotypes for farmers use. Experiment conducted pot greenhouse in Rubona-reserch site in Rwanda to identify as superior genotypes and nodulation of both bush and climbing bean genotypes under acidic, low phosphorus soils, results showed that highest score was $22.9 \mathrm{~g} /$ pot for climbing bean which agreed with this study (Gatesi and Nsanzimana, 2017). Islam, et al., (2016) did a study on yield response of three beans, bush, winged and long genotypes under organic fertilizers growing conditions, they found significant variation in yield whereby some genotypes produced as high as $2980 \mathrm{~kg} / \mathrm{ha}$, which agree to the current result. Also, Singh et al., (2013) observed the high yield genotypes with tolerance to sodic soils were the best genotypes selected by farmers in rice experiment in India, which supports also this experiment.

The increase in production will be realized with the adoption of high yielding, good market, and early maturity varieties as mentioned by farmers at their locations from this study. Genotypes MAC44 and RWV were selected basing on the criteria mention above during farmers participatory variety selection. High yield was the first criteria for adoption of rice variety to grow in salt soils in India (Singh et al., 2013) which agreed with our study. Also, similar results obtained by Pandit et al., 2006 during his studies conducted to replace susceptible wheat in India. A study conducted in Ethiopia to determine which varieties farmers would adopt and replace the old of which farmers mentioned good market as the criteria in choosing a soybean genotypes to cultivate which agreed with this study (Getahun et al., 2016).

\section{CONCLUSION}

This study concluded that genotypes such as RWV1129 and MAC44 performed consistently highly in both seasons. They produced $3398 \mathrm{~kg} / \mathrm{haand} 3530 \mathrm{~kg} / \mathrm{ha}$, respectively in 2014/15 cropping season. In the next season (2015/16), RWV 1129 produced $3091 \mathrm{~kg} /$ ha while MAC44 produced $2910 \mathrm{~kg} / \mathrm{ha}$. Both genotypes were ranked first and second in farmer's participatory variety selection because of their high yielding potential, high market value, and resistance to diseases. The study also revealed that farmers selection criteria vary with locations because farmers in the western zone were drought tolerance, high yield and early maturing variety whereas in northern zone were high yield, market value and disease resistance. MAC 44 and RWV 1129 were recommended for registration as good varieties for cultivation in Tanzania.

\section{Acknowledgement}

The authors would like to acknowledge CIAT/PABRA for financial support; Selian/Uyole/Maruku Agricultural Research Institutes and farmers for providing the fields for the experiments and moral participation on farmers in participatory variety selection. 


\section{References}

Blair, M.W. (2013). Mineral Biofortification Strategies for Food Staples: The Example of Common Bean. J. Agric. Food Chem. 61:8287-8294.

Checa, O., Herna', N. C., and Matthew. W. B. (2006). Generation Means Analysis of Climbing Ability in Common Bean (Phaseolus vulgaris L.). Journal of Heredity 97(5):456-465

FAO, (2012). FAOSTAT. Food and Agriculture Organization of the United Nations.

Gatesi and, J., and Nsanzimana, O. (2017). Responses of Nodulation and Grain Yield to fertilization with Phosphorus (P) of Outstanding Low P Tolerant Phaseolus vulgaris L. Genotypes in Highly Acidic and Phosphorus Deficient Soils Such of Rwanda. International Journal of Plant \& Soil Science. 18(2):1-10.

Getahun, A., Atnaf, M., Abady, S., Degu, T., and Dilnesaw, Z. (2016). Participatory Variety Selection of Soybean (Glycine max (L.) Merrill) Varieties Under Rain Fed Condition of Pawe District, North-Western Ethiopia. International Journal of Applied Science and Mathematics 3(2): 2394-2894.

Islam, M.A., Amru, N. B., Rahman, M.M., Mohd, S.A., and Muhammad, A. A. (2016). Effects of organic fertilizers on the growth and yield of bush bean, winged bean and yard long bean. Brazilian archives of biology and technology 59: 1678-4324.

Kaizzi, K.C., John, B., Onesmus, S., Isaac, A., Williams, Z., Angella, N., Patrick. M., Peter, E., Theodore, H., and Charles, S. W. (2012). Maize Response to Fertilizer and Nitrogen Use Efficiency in Uganda Agron. $J$. 104:73-82.

Lin, L., Tao, Y., Rong, L., Bob, R., Fouad, M., Xuxiao, Z. (2016). Food legume production in China. The Crop Journal 10:10-16.

Muhimbula, H.S., and Zacharia, A.I. (2010). Persistent child malnutrition in Tanzania: Risks associated with traditional complementary foods (A review). African Journal of Food Science 4(11): 679 - 692.

Pandit, B.P., Slam, M.M., Arunurrashid, M.H., and Ufian, M.A. S. (2006). Participatory variety selection in wheat and its impact on scaling-up seed dissemination and varietal diversity. Bangladesh J. Agril. Res. 32(3): 473486.

Petry, N., Erick, B.., James, P. W., and Richard, F. H. (2015). The Potential of the Common Bean (Phaseolus vulgaris) as a Vehicle for Iron Biofortification. Nutrients, 7: 1144-1173.

Singh, Y. P., Nayak, A. K., Sharma, D. K., Gautam, R. K., Singh, R.K., Ranbir Singh, V. K., Mishra, T. P., and Ismail A.M. (2013). Varietal selection in sodic soils of Indo-Gangetic plains through farmers' participatory approach. African Journal of Agricultural Research 8(23):2849-2860. 